\title{
СИСТЕМНИЙ ТА ЛОКАЛЬНИЙ ІМУНІТЕТ ПРИ УРОГЕНІТАЛЬНІЙ ІНФЕКЦІЇ У ЖІНОК З ПОРУШЕННЯМ РЕПРОДУКТИВНОЇ ФУНКЦІї
}

\section{Со.П. Гнатко, Н.Г. Скурятіна}

Національний медичний університет імені О.О. Богомольця

РЕЗЮМЕ. Обстежено 120 жінок з урогенітальною інфекцією віком від 18 до 40 років, які мали порушення репродуктивної функції. Проведена оцінка стану загального і місцевого гуморального імунітету у жінок із запальними захворюваннями геніталій залежно від наявності моно-інфекції (чистий хламідіоз) чи мікст-інфекції (хламідіоз в поєднанні з бактеріальними мікроорганізмами і вірусами). Показано, що найбільш виражені зміни в системі загального і місцевого імунітету мали місце при хламідійній інфекції в поєднанні з бактеріальними асоціаціями мікроорганізмів та вірусами. Це призводить до хронічних рецидивуючих запальних процесів в статевих органах і до порушення репродуктивної функції жінок.

КЛЮчОВІ СЛОВА: системний і місцевий імунітет, репродуктивна функція, запальний процес, статеві органи, інфекція.

Вступ. Проблема захворювань статевих органів у жінок, зумовлених урогенітальними інфекціями, продовжує залишатись актуальною протягом тривалого часу, оскільки одним із найсуттєвіших негативних моментів, що пов'язані $з$ цією патологією, є порушення репродуктивної функції у жінок [2]. Основним пусковим механізмом запалення $є$ інфекційні агенти, а також порушення в системі загального і місцевого імунітету. Активність інфекційних чинників залежить від багатьох факторів: біологічних властивостей самих мікроорганізмів, особливостей їх локального і генералізованого впливу на організм, а також від взаємодії між організмом жінки та інфекційним чинником [2]. Серед збудників, які призводять до виникнення запального процесу геніталій, переважають хламідії, уреаплазми, мікоплазми, віруси, які зустрічаються переважно у вигляді різноманітних асоціацій. Інфекції, що передаються статевим шляхом, є основною причиною вторинних імунодефіцитів, які створюють передумови для приєднання умовно-патогенної мікрофлори і формування хронічних, рецидивуючих запальних процесів статевих органів у жінок $[1,3,7]$ Дослідженнями останніх років доведено, що в значній частині випадків при інфікуванні статевих органів хламідіями запальний процес обумовлює тривалий перебіг захворювання у жінок 3 порушенням репродуктивної функції. [4] Рецидивуючий характер запалення часто обумовлений приєднанням вірусів. Вибір ефективних методів лікування повинен бути розроблений з урахуванням захисної системи організму жінки, яка формується залежно від взаємозв'язку макро- і мікроорганізму. Тому дуже важливим є вивчення стану системного і локального імунітету у жінок 3 урогенітальною інфекцією залежно від наявності у них моночи мікст-інфекції.
Мета дослідження. Вивчення стану системного і локального гуморального імунітету при урогенітальній інфекції у жінок з порушеннями репродуктивної функції.

Матеріал і методи дослідження. Обстежено 120 жінок з урогенітальною інфекцією віком від 18 до 40 років, які мали порушення репродуктивної функції і 20 здорових жінок тієї ж вікової групи. В процесі дослідження вивчали анамнез, скарги жінок, характер та тривалість запального процесу, становлення менструальної функції, початок статевого життя, гінекологічний статус. При клінічному обстеженні оцінювали стан зовнішніх статевих органів (огляд в дзеркалах, кольпоскопія шийки матки) та внутрішніх статевих органів (бімануальне дослідження, ультразвукова діагностика). Вид інфекційного збудника запального процесу встановлювали за допомогою комплексного бактеріоскопічного, мікробіологічного та цитологічного досліджень зскрібків із слизової оболонки піхви, цервікального каналу шийки матки та уретри. Мазки забарвлювались за Романовським-Гімзою та за Грамом $[4,8]$. Бактеріоскопія доповнювалась культуральним виявленням бактерій у пробах патологічного матеріалу [4]. Для виявлення уреаплазми та мікоплазми застосовували комплекс методів: реакцію імунофлюоресценції (РIФ), тест-системи Mycoplasma DUO, ланцюгово-полімеразну реакцію (ЛПР). Хламідії виявляли за допомогою ЛПР та РІФ. Гарднерели діагностували за допомогою ЛПР та виявлення "ключових клітин" при бактеріоскопічному дослідженні. Віруси групи герпесу I-ІІ типів досліджували за допомогою ЛПР. Крім того, в пробах крові визначали наявність антитіл до хламідіозу і вірусів групи герпесу I-II типів.

Оцінка стану системного імунітету в обстежених включала визначення показників клітинної та гуморальної ланок. Визначення Т-лімфо- 
Огляди літератури, оригінальні дослідження, погляд на проблему, короткі повідомлення, замітки з практики

цитів (СД3+) та їх субпопуляцій: Т-хелперів (СД4+), Т-супресорів (СД8+) проводилось за допомогою наборів моноклональних антитіл cepiï Leu (Becton Dickinson, США). Дослідження гуморальної ланки включало кількісне визначення вмісту IgA, M, G методом радіальної імунодифузії в гелі за Манчіні [9]. Рівень циркулюючих імунних комплексів (ЦІК) визначали за методом V. Hashkova і співавторів [3]. Вміст г-ІНФ, ІЛ-1, ІЛ-10, ФНП-б визначали за допомогою імуноферментного аналізу. Оцінка стану місцевого гуморального імунітету проводилась за допомогою визначення концентрації імуноглобулінів (Ig) класів A, M, G та slgA в змивах секрету з цервікального каналу шийки матки методом простої радіальної імунодифузії в гелі за Манчіні [9]

Статистичну обробку отриманих даних здійснювали за допомогою пакета статистичних програм "STATISTICA for Windows S.O."

Результати й обговорення. Результати мікробіологічного та серологічного досліджень обстежених жінок показали, що етіологічними факторами запального процесу геніталій були як моно-, так і мікст-інфекції. Залежно від цього всі жінки були поділені на чотири групи. До першої групи ввійшло 38 (31,7%) жінок 3 моноінфекцією (чистий хламідіоз). Другу групу склали 44 (36,7\%) жінки 3 хламідіями в поєднанні з уреаплазмами, гарднерелами, трихомонадами До третьої групи ввійшло 18 (15,0%) жінок з хламідіями в поєднанні з вірусами герпесу 1 та 2 типів. В четверту групу увійшли 20 ( 16,0\%) жінок з хламідійною інфекцією в асоціації з неспецифічною мікрофлорою (E. coli, St. aureus, St. epidermalis, Enterococcus faecalis, Str. Angemaliticus) у критичному мікробному числі ( $10^{5}$ - $10^{6} \mathrm{KDE} / \Gamma$ ).

Клінічний аналіз перебігу запального процесу геніталій показав, що у жінок першої групи він характеризувався латентним розвитком рецидивами до 1-2 разів на рік. Запальний процес у жінок другої, третьої і четвертої груп характеризувався затяжним хронічним розвитком з частими загостреннями захворювання, особливо у жінок третьої групи ( до 2-3 разів на рік). Запальний процес супроводжувався вираженими суб'єктивними відчуттями: виділеннями із статевих шляхів - у 69 (57,5 \%) пацієнток, подразненням та свербежем - у 18 (15\%) пацієнток, болем унизу живота - у 27 (22,5 \%) пацієнток, дизуричними явищами - у 7 (5,8 \%) пацієнток.

Із гінекологічного анамнезу встановлено, що $80(66,7 \%)$ жінок не народжували. 40 (33,3\%) жінок мали пологи; із них 34 (85 \%) жінки народжували один раз, 10 (15\%) - двічі. Штучні аборти мали 24 (20 \%) пацієнтки.
При огляді в дзеркалах у 25 (65,8 \%) пацієнток 1 групи, у 32 (72,7 \%) пацієнток 2 групи, у $10(55,6 \%)$ пацієнток 3 групи і у $13(65,0 \%)$ пацієнток 4 групи спостерігались виділення, набряк та гіперемія зовнішнього вічка шийки матки. При бімануальному дослідженні у 11 (28,9 \%) жінок 1 групи, у 15 (34,1\%) жінок 2 групи, у 4 ( $22,2 \%)$ жінок 3 групи і у 7 (35,0 \%) жінок 4 групи було діагностовано сальпінгоофорит; відповідно: у 5 (13,2 \%), 6 (15,0 \%), 2 (11,1\%), 2(10\%) пацієнток - доброякісні пухлини яєчників.

При вивченні стану шийки матки встановлено, що в 67 \% випадків запальні процеси шийки матки супроводжувались пошкодженням покривного епітелію шийки матки. Кольпоскопічно і цитологічно було виявлено такі захворювання шийки матки: ендоцервіцит спостерігався у 10 (26,3 \%) жінок 1 групи, у 7 ( 17,5 \%) жінок 2 групи, у 2 (11,1\%) жінок 3 групи і у 4 (20\%) жінок 4 групи; доброякісні процеси шийки матки зустрічались відповідно: у 21 (55,3\%), 22 (52,3 \%), 7 (38,9 \%), 9(45 \%) жінок, диспластичні процеси зустрічались відповідно: у 4 (10,6 \%), 11 (27,5 \%), 5 (27,8 \%), 4(20 \%) жінок. 3 отриманих даних видно, що захворювання шийки матки мали односпрямований характер незалежно від моно- чи мікст-інфекції, що можна пояснити домінуванням в запальному процесі хламідійної інфекції.

При ультразвуковому обстеженні у жінок були виявлені такі патології: полікістоз яєчників - у 4 (10,5 \%) пацієнток 1 групи, у $5(11,4 \%)$, пацієнток 2 групи, у 1 (5,6 \%) пацієнтки 3 групи і у 2 (10\%) пацієнток 4 групи; кісти яєчників відповідно: у 5 ( $13,2 \%), 6(15,0 \%), 2(11,1 \%), 3$ (15\%) пацієнток; ендометріоз внутрішніх статевих органів - відповідно: у 1 (2,6 \% ), 2 ( 4,5 \%), $0(0 \%), 1(5 \%)$ пацієнток; гіперплазія чи поліпоз ендометрію - відповідно: у 2 (5,3\%), 4 (9,1\%), 3 $(16,7 \%), 2$ (19 \%) пацієнток; хронічний сальпінгоофорит - відповідно: у 11 (28,9 \%), 15 (34,1\%), $4(22,2 \%), 7(35, \%)$ жінок; хронічний ендометрит - відповідно: у 1 (2,6\%), 2 (4,5\%), 2 (11,1\%), 1 (5\%) жінок. 3 отриманих даних видно, що у жінок з бактеріальною інфекцією (моно- або мікст-) частіше зустрічаються хронічні запальні захворювання додатків матки.

Реакція імунної системи на запальний процес, викликаний урогенітальною інфекцією, вивчалась за рядом критеріїв (таблиця 1). Результати імунологічного обстеження показали, що у пацієнток усіх чотирьох груп спостерігались значні зміни у показниках клітинної ланки імунітету, ці зміни мали односпрямований характер. 3 таблиці видно, що має місце дефіцит СД3+ СД4+ клітин. Найбільше рівень СД3+ і СД4+ еле- 
Оеляди літератури, оригінальні дослідження, погляд на проблему, короткі повідомлення, замітки з практики ментів пригнічувався у пацієнток третьої групи. Найсуттєвіше зниження СД4+/СД8+ індексу також спостерігалось у жінок 3 групи. В гуморальній ланці імунітету спостерігалось підвищення концентрації імуноглобулінів G, М і А. Високий рівень ЦІК також є показником імунодепресії і разом із високим титром імуноглобулінів підтверджує наявність запального процесу.

Аналіз цитокінової ланки імунітету показав зниження рівня гІНФ і підвищення рівня ІЛ-10 у пацієнток усіх груп. У пацієнток з мікст-інфекцією

рівень ФНП-б майже у 2 рази перевищував рівень ФНП-б у жінок з моно-інфекцією. Це можна пояснити різноманітним спектром антигенів у пацієнток із мікст- інфекцією.

У місцевому імунітеті виявлено підвищення рівня lgM i lgG і зниження концентрації slgA. Зниження рівня slgA вказує на порушення процесів синтезу секреторного компонента клітинами епітелію при урогенітальній інфекції.

Після детального обстеження жінок встановлено порушення їх репродуктивної функції. В першій

Таблиця 1. Показники системного і місцевого імунітету у жінок з урогенітальною інфекцією

\begin{tabular}{|c|c|c|c|c|c|c|}
\hline № & Показник & $\begin{array}{c}\text { Норма } \\
\text { (контроль) }\end{array}$ & 1 група & 2 група & 3 група & 4 група \\
\hline 1 & $\begin{array}{l}\text { Т-лімфоцити } \\
\text { (СД3+), \% }\end{array}$ & $59,9+\_1,5$ & $39,0+\_1,2^{*}$ & $36,2+0,9 *$ & $34,6+\_1,4^{*}$ & $38,7+-1,2 *$ \\
\hline 2 & $\begin{array}{l}\text { Т-хелпери } \\
(\text { СД4+), \% } \\
\end{array}$ & $27,6+\_1,3$ & $22,5+\_1,3 *$ & $20,7+0,7 *$ & $18,3+\_1,4^{*}$ & $22,9+-1,0^{*}$ \\
\hline 3 & $\begin{array}{l}\text { Т-супресори } \\
\text { (СД8+), \% }\end{array}$ & $22,3+[0,9$ & $21,2+\_1,8$ & $20,5+\_1,0$ & $23,3+\ldots 1,3$ & $20,8+-1,4$ \\
\hline 4 & $\begin{array}{l}\text { Імунорегуля- } \\
\text { торний } \\
\text { iндекс } \mathrm{T}_{\mathrm{x}} / \mathrm{T}_{\mathrm{c}}\end{array}$ & $1,6+[0,05$ & $1,23+[0,09 *$ & $1,16+\_1,07^{*}$ & $1,09+0,08^{*}$ & $1,21+-1,03^{*}$ \\
\hline 5 & $\operatorname{IgA}$, Г/л & $0,06+0,09$ & $1,36+0,18^{*}$ & $1,39+0,19 *$ & $1,38+0,18^{*}$ & $1,35+-0,18^{*}$ \\
\hline 6 & $\mathrm{IgG}$, Г/л & $11,5+1,2$ & $30,2+1,4^{*}$ & $31,8+2,9^{*}$ & $27,3+1,9^{*}$ & $30,8+-1,8^{*}$ \\
\hline 7 & IgM, г/л & $1,33+0,2$ & $1,58+0,15$ & $1,69+0,17$ & $1,61+0,16$ & $1,60+-0,15$ \\
\hline 8 & ЦІК, од. екст. & $55,40+44,2$ & $75,53+7,5^{*}$ & $77,67+8,2 *$ & $73,91+55,9 *$ & $74,91+-7,4^{*}$ \\
\hline \multicolumn{7}{|c|}{ Цитокіни } \\
\hline 9 & ІЛ-1, пкг/МЛ & $112,8+6,0$ & $211,1+22,3^{*}$ & $116,3+19,8^{*}$ & $121,2+21,2 *$ & $128.2+-20,3 *$ \\
\hline 10 & ІЛ-10, пкг/мл & $154,1+14,41$ & $306,72+19,43^{*}$ & $361,62+29,50 *$ & $386,64+28,66^{*}$ & $317,6+-18,99 *$ \\
\hline 11 & $\gamma \mathrm{IH} \Phi$, пкг/мл & $23,80+0,44$ & $12,3+0,8^{*}$ & $14,2+0,36^{*}$ & $21,4+0,53^{*}$ & $13,1+-0,76^{*}$ \\
\hline 12 & ФНП- $\alpha$, пкг/мл & $16,82+0,91$ & $12,3+1,5^{*}$ & $31,2+1,23^{*}$ & $33,4+1,07^{*}$ & $30,1+-1,09^{*}$ \\
\hline \multicolumn{7}{|c|}{ Показники місцевого гуморального імунітету } \\
\hline 13 & $\operatorname{IgA,~Г/л~}$ & $0,076+0,005$ & $0,06+0,005^{*}$ & $0,056+0,006^{*}$ & $0,059+0,005^{*}$ & $0,058+-0,005^{*}$ \\
\hline 14 & $\mathrm{IgG}$, Г/л & $0,65+0,05$ & $0,96+0,05^{*}$ & $0,97+0,07 *$ & $0,98+0,05^{*}$ & $0,94+-0,05^{*}$ \\
\hline 15 & $\operatorname{IgM,~Г/л~}$ & 0 & $0,15+0,01 *$ & $0,17+0,01^{*}$ & $0,19+0,01 *$ & $0,16+-0,01^{*}$ \\
\hline 16 & $\operatorname{sIg} \mathrm{A}$, г/л & $0,5+0,05$ & $0,17+0,08^{*}$ & $0,14+0,05^{*}$ & $0,11+0,06^{*}$ & $0,18+-0,05^{*}$ \\
\hline
\end{tabular}

Примітка. вказана вірогідність $(p<0,05)$

* - в порівнянні з контролем

групі пацієнток з неплідністю було $821 \%$ ), при чому первинна неплідність - у 6 (16\%) і вторинна неплідність - у 2 (5 \%) жінок; самовільні викидні зустрічались у 4 (11\%) жінок, завмерлі вагітності у строках 8-12 тижнів - у 3 (8 \%) жінок, ектопічна вагітність - у 3 (8\%) жінок. У 3 (8\%) пацієнток цієї групи, що народжували, пологи ускладнились передчасним чи раннім відходженням навколоплідних вод.

У другій групі самовільні викидні зустрічались у $5(11 \%)$ жінок, завмерлі вагітності - у 4 (9\%) жінок, ектопічна вагітність - у 4 (9\%) жінок; пацієнток з неплідністю було 6 (14\%). У 5 (11\%) жінок цієї групи, що народжували, пологи уск- ладнились передчасним чи раннім відходженням навколоплідних вод і у 2 (5 \%) жінок - післяпологовим ендометритом.

У третій групі відмічались порушення репродуктивної функції у вигляді: невиношування вагітності у 5 (28 \%) пацієнток (при цьому самовільні викидні в першому триместрі вагітності зустрічались у $3(17 \%)$ жінок і у $2(11 \%)$ жінок спостерігались пізні викидні у строках 20-22 тижні вагітності), у 3 (17 \%) жінок були завмерлі вагітності; пацієнток з неплідністю було 2 (11\%). У 2 (11\%) жінок цієї групи, що народжували, пологи були передчасними і у 1 (6 \%) жінки пологи ускладнились передчасним чи раннім відходження навколоплідних вод. 
Огляди літератури, оригінальні дослідження, погляд на проблему, короткі повідомлення, замітки з практики

В четвертій групі самовільні викидні зустрічались у 3 (15\%) жінок, завмерла вагітність у 1 (5\%) жінки, ектопічна вагітність - у 1 (5\%) жінки; пацієнток з неплідністю було 3 (15\%). У 1 (15\%) жінки цієї групи, що народжувала, пологи ускладнились передчасним відходженням навколоплідних вод і у 1 (5 \%) жінки - післяпологовим ендометритом.

3 представлених даних видно, що неплідність та ектопічна вагітність частіше зустрічались у жінок з хламідійною інфекцією, як у чистому вигляді, так і в асоціаціях з іншими бактеріями. Ускладнення пологів у вигляді передчасного чи раннього відходження навколоплідних вод і післяпологового ендометриту частіше спостерігалось у жінок з поєднанням хламідійної інфекції з бактеріальними мікроорганізмами У пацієнток з бактеріально-вірусною асоціацією мікроорганізмів частіше зустрічались завмерлі вагітності і передчасні пологи. Невиношування вагітності спостерігалося у пацієнток всіх груп приблизно з однаковою частотою.

Висновки. Таким чином, отримані дані свідчать, що запальні захворювання геніталій

\section{ЛІТЕРАТУРА}

1.А.Г. Корнацкая, Т.Д. Задорожная, О.Ю. Борисюк и соавт. Сравнительная клинико-морфологическая характеристика особенностей органов-мишеней репродуктивной системы у женщин с хронической вирусно-бактериальной инфекцией // Здоровье женщины. - 2005.- №1 (21).- С. 107-110.

2.О.В Ромащенко., Л.Ф. Яковенко., А.В. Руденко та ін. Показники імунітету у дівчат-підлітків та юних жінок із запальними захворюваннями органів малого таза // Педіатрія, акушерство та гінекологія, №1. 2002p. - C.78-83. викликані урогенітальною інфекцією, супроводжуються дисфункцією імунної відповіді, що проявляється порушеннями в системі загального місцевого імунітету. Особливості стану системного і локального імунітету визначаються наявністю в запальному процесі моно- (чистий хламідіоз) чи мікст-інфекції (хламідіоз в асоціаціях 3 бактеріями і вірусами). Найбільш виражені зміни в системному і місцевому імунітеті відбуваються у пацієнток з хламідіями у вигляді мікст-інфекції як $з$ бактеріями, так і з вірусами. Запальний процес, викликаний мікст-інфекцією, характеризується хронічним затяжним перебігом з частими рецидивами і супроводжується значними анатомічними змінами в статевих органах, що призводить до порушення репродуктивної функції у жінок.

Перспективи подальших досліджень. Вивчення особливостей загального і місцевого імунітету в залежності від наявності моно- чи мікст-інфекції має важливе значення для розробки ефективних методів лікування у жінок 3 урогенітальною інфекцією для профілактики порушень репродуктивної функції.

3. Руденко А.В., Ромащенко О.В., Яковенко Л.Ф. та інші. Показники інтерферонового статусу та продукція фактору некрозу пухлин у юних жінок із запальними захворюваннями внутрішніх статевих органів // Імунологія та алергологія.- 2000. - № 2-3.C. $43-46$

9. Mancini G. Carbonara A.O., Heremans J.E. Immunochemical quantitation of antigens by single radia immunodiffusion //Immunochemistry. - 1965. -Vol. 2; № 3 - P. 235-254.

\section{SYSTEM AND LOCAL IMMUNITY AT UROGENITAL TRACT INFECTION IN WOMEN WITH REPRODUCTIVE DISORDERS}

○).P. Hnatko, N.H. Skuryatina

National Medical University by O.O. Bohomolets

SUMMARY. 120 women aged from 18 to 40 years with urogenital infection who had reproductive disorders were studied. State of general and local humoral immunity was studied in women with genital inflammatory diseases depending on presence of monoinfection (pure chlamidiosis) or mixed infection (chlamidiosis in combination with bacteria microorganisms and viruses. It was shown that the most pronounced changes in general and local immunity occurred at Chlamydia infection in association with pathogens and viruses. This leads to chronic recurrent inflammatory processes of genitals and reproductive function disorders.

KEY WORDS: general and local immunity, inflammation, urogenital infection, reproductive function, genitals. 
Огляди літератури, оригінальні дослідження, погляд на проблему, короткі повідомлення, замітки з практики УДК 618.1-007.575.191

\section{ГЕНЕТИЧНІ АСПЕКТИ ПРОЛАПСУ ВНУТРІШНІХ СТАТЕВИХ ОРГАНІВ У ЖІНОК}

(С.П. Григоренко, О.Г. Шиманська, Н.І. Карпекіна

Вінницький національний медичний університет ім. М.І. Пирогова

РЕЗЮМЕ. Досліджено вплив генетичних чинників у жінок з пролапсом внутрішніх статевих органів. Виявлено, що генетичний вклад складає, за даними дерматогліфіки, 48,8 \%, генеалогії - 73,3 \% та цитогенетики - 24,0 \%. КЛЮчОВІ СЛОВА: пролапс матки, дерматогліфіка, генеалогія, цитогенетика.

Вступ. Пальцева дерматогліфіка є одним 3 інтегральних показників організму. Інформація про особливості генотипу індивідуума зберігається як у формі гребенястих візерунків, так і в їхній топографії на пальцях [1]. Значущість розподілу шкірних візерунків за типами залежить від структури хромосом, особливо статевих [2]

Закладка гребенястої шкіри починається в кінці першого триместру внутрішньоутробного розвитку плода, а диференціювання гонад закінчується до кінця 8-го тижня [3]. У Х-хромосомі містяться гени, які відповідальні за формування статі та утворення гребенястої шкіри $[4,5]$, обумовлює високу частоту дуг та петель і зменшення гребенястого ліку, а Ү-хромосома - високу частоту завитків та збільшення гребенястого ліку [6]. Спостерігається значний відсоток особливостей шкірного рельєфу в жінок з вадами розвитку сечостатевої системи хромосомного генезу [7], вадами розвитку піхви та матки [8] Ембріональні подушечки, під впливом яких утворюються шкірні візерунки, формуються 3 ектомезенхіми на ранньому етапі ембріонального розвитку з цілим рядом інших структур [9]. Збільшення або зменшення гребенястого ліку, дистальне зміщення осьового трирадіуса, редукція або відутність пальцевого трирадіуса С, на явність вираженої чотирипальцевої борозни, підвищена покресленість шкіри долонь властиві багатьом спадковим порушенням [6]. Геном кожної особи характеризується унікальною комбінацією поліморфних варіантів ділянок конститутивного або С-гетерохроматину за величиною та особливостями локалізації на хромосомах [10]

У патогенезі розвитку пролапсу геніталій у жінок молодого віку провідну роль відіграє системна дисплазія сполучної тканини, яка має прояви на рівні всіх органів і систем організму, а пролапс $€$ частковим її виявленням [11]

Мета дослідження. Визначити вклад генетичних чинників у формуванні пролапсу внутрішніх статевих органів у жінок з метою ранньої профілактики даної патології.

Матеріал і методи дослідження. Виконано дерматогліфічне, генеалогічне та цитоге- нетичне обстеження жінок віком 35-75 років 3 пролапсом внутрішніх статевих органів, яким проведено хірургічне лікування.

Контрольну групу склали фенотипово та соматичне здорові жінки з нормальною репродуктивною функцією. Відбиток рук (308 долонь та 1540 пальців) отримували за допомогою чорної друкарської фарби на білому папері з подальшим вивченням [5]. Дослідження візерунків шкіри проводили за методикою Cummis та Midid з використанням класифікації Генрі [6].

Вивчали 9 груп показників: 1) тип рисунка кінцевих фаланг пальців; 2) величина гребенястого ліку (пальцевий, долонний, загальний); 3) пальцеві трирадіуси; 4) осьові трирадіуси (наявність, зміщення, кут atd); 5) рисунок долонних подушечок (гіпотенар, тенар, I, II, III, IV); 6) закінчення долонних головних ліній А, В, C, B; 7) згинальні складки долоні (покресленість, поперечна чотирипальцева борозна та їі варіанти); 8) дельтоподібний індекс; 9) тотальний індекс головних ліній долоні. Усього вивчено 45 ознак.

Генеалогічний метод дослідження [12] використовували 3 дотриманням таких правил: родовід зображався так, що кожне покоління знаходилось на своїй горизонталі; сибси розташовувались у порядку народження зліва направо. Зображення ліній матері та батька включало міжнародну систему символів. Чоловіки родичок пробанда зображались нижче лінії родичок, якщо вони здорові та не впливали на виникнення даного захворювання, взагалі опускалися. Проведено вивчення родоводів у 35 жінок 3 пролапсом геніталій. Матеріалом для цитологічного дослідження були лімфоцити венозної крові 25 жінок 3 пролапсом внутрішніх статевих органів.

Стерильний забір крові й культивування клітин здійснювали відповідно до стандартної методики каріотипування (напівмікрометод). Клітини крові культивували 48-52 год при температурі $37{ }^{\circ} \mathrm{C}$ в середовищі PB max і 90 хв 3 кальцемідом (0,1 мкг/мл) для накопичення лімфоцитів на стадії метафази. Для кожної пацієнтки ставили декілька паралельних культур. 